important, relaxation of the muscle is complete in between the contractions, so that the blood supply to the placenta is disturbed only for short periods of time.

\section{Induction of Labour}

The medical induction of labour, as introduced in 1913, consisted of a combination of quinine, castor oil, enema, and, when necessary, injections of post-pituitary extract. Quinine kills babies, particularly if the mother suffers from hypertension and proteinuria, and should never be given for this purpose unless the foetus is dead, when it is most useful.

The antibiotics and sulphonamides, together with the oxytocin drip, have relegated medical induction of labour to the limbo of forgotten procedures, for (unless quinine is given) it works only when the woman is ready to undertake parturition. Provided the woman is at or near term, and the cervix is reasonably ripe, labour can be induced in $80 \%$ of patients by sweeping and rupturing the membranes, and administering a purgative and an enema. Castor oil seems to be the most efficient purgative for this purpose.

\section{Oxytocin Drip}

If the woman is not in labour on the morning after that on which the membranes were ruptured, a physiological oxytocin drip can be used. It is recommended that $\frac{1}{2}$ unit of either injection of oxytocin B.N.F. (pitocin) or syntocinon be added to the drip bottle containing $540 \mathrm{ml}$. of $5 \%$ glucose in sterile water, and run at not more than 40 drops a minute. A unit can be added to the next bottle, but it is not safe to leave any woman without careful supervision if more than 1 unit is added to the bottle.

\section{Treatment of Uterine Inertia}

The most valuable single procedure is to make sure that there is no cephalopelvic disproportion and then to sweep and rupture the membranes, allowing as much liquor amnii as possible to escape. An enema should be given, and a purgative, unless labour is far advanced. The physiological oxytocin drip may cause an immediate improvement in uterine activity. If the woman is exhausted, deep sedation is indicated. Relief of pain is not enough; sleep is essential. If the foetus is premature, the amount of morphine or pethidine given should be strictly limited, but otherwise full doses of morphine can be given, for its effects can be controlled by an intramuscular injection of $10 \mathrm{mg}$. of nalorphine injection B.N.F. ("lethidrone") shortly before delivery occurs.

Prolunged ineffectual labour often upsets the electrolyte balance and raises the intrathecal pressure. The intravenous infusion of from $\frac{1}{2}-1$ litre of $20 \%$ glucose may prove valuable. Should delivery be delayed when the head is at the outlet or on the perineum, and neither mother nor baby is showing signs of distress, it is permissible to inject 2 units of either pitocin or syntocinon intramuscularly while the forceps are being sterilized. This can be repeated in ten minutes' time provided the first injection caused no anxiety.

\section{Prevention of Post-partum Haemorrhage}

The intravenous injection of ergometrine or methyl ergometrine, as soon as the head is born (or the anterior shoulder is delivered), is thought by many to be of value in preventing post-partum haemorrhage. If no doctor is present the drug can be injected intramuscularly.
Should extraction of the infant prove difficult or there be an unsuspected twin, ergometrine will probably kill the infant. For this reason it is better for the doctur to await delivery before injecting the ergometrine intravenously, and in my view it is sound practice to give 2 units of syntocinon intramuscularly as soon as the head is crowned.

\section{Treatment of Post-partum Haemorrhage}

After removal of the placenta ergometrine should be given intravenously. If no doctor is present the haemorrhage can usually be controlled by the intramuscular injection of ergometrine. Should the haemorrhage be associated with fibrinogenopaenia, blood plasma must be infused intravenously.

\section{Involution of the Uterus}

Early ambulation, the easy control of minor degrees of uterine infection, and the safety of exploring the uterus have much diminished the need for oxytocic agents during the puerperium, but they probably still have a place. I have an old-fashioned predilection for using the liquid extract of ergot, together with dilute sulphuric acid, but the important point is that the treatment should not last for more than six days and that it should be withheld if there is any suggestion of hepatic deficiency.

\section{THE G.P. AND CLINICAL PATHOLOGY}

BY

\section{STARK MURRAY, M.B., Ch.B., B.Sc. Group Pathologist, Kingston Hospital, Surrey}

It is 30 years since I first offered an "open access" laboratory service to a group of general practitioners, and it seems worth while reviewing the present position and looking at the changing scene as a guide to future needs. The district to be looked at is not precisely that in which the service was first given, though it includes parts of it, but the service at Kingston has been continuous and developing for 22 of those years and probably offers as wide an experience in the field as any in Britain. Reports on the laboratories have already been made (Murray, 1944, 1951) and some comparisons can be made with profit.

In so far as the experience here may be exceptional it must be viewed against my connexion with the London County Council's early attempt at a group laboratory service, and.my advocacy of the open-access principle (Murray, 1931), and of the Emergency Pathology Service (Murray, 1941). Throughout all of these the principle applied was that later accepted by the Nuffield Provincial Hospitals Trust (1941) that " every sick person, irrespective of his or her income, must be able to have pathological examinations made for the diagnosis and treatment of disease. This must apply to the sick in their homes as well as in hospital." That principle has been applied in a period of fee-paying medicine, in a wartime service, under a county council, and for 11 years under the National Health Service. It follows that the general practitioners in the area served have long been accustomed to making full use of the service almost entirely without abuse and in many instances with considerable wisdom. 
The hospital group under survey is that previously reported upon (Murray, 1951) and has changed only a little in the perlud. The population is over 200,000 and has 1,1110 hospital beds, which is far below the number nerded for an "ideal" service. The group laboratory has one satellite laboratory serving 120 beds with its oun medical and technical staff, so that its figures have not been included in the present discussion. It can be claimed that, though neither lavishly staffed nor equipped, the Kingston Group Laboratory is capable of doing all the routine work that can be expected in a large hospital laboratory, and the only tests now sent to central laboratories are those in virology, in radioactive isotope tests, and for the identification of rare bacteria. All doctors using the service are encouraged to regard it as their first place of reference for all scientific investigations and to leave it to the laboratory to consult higher experts when necessary.

\section{The General Practitioner}

Just on 100 general practitioners use the laboratory, but a number are from the fringes of the area, and for the present purpose only those 81 who can really be counted as having their practice entirely inside the area have been included. What was said about the general practitioners in 1951 still stands, except that there seems to have been an ironing-out process so far as very large practices are concerned, and the average list is now based on a smaller range and is said to be about 2,300 . There have been many changes in the period, but the general impression everyone has in the area is that the professional standard of service is high, and the existence of open-access laboratories and $x$-ray departments is given some of the credit for that standard. The laboratory has made a deliberate effort to encourage the general practitioner, and monthly "clinico-pathological conferences" are always well attended.

The grow'th of the laboratory service has been continuous in spite of the varying controls indicated above. In 1939 there were two part-time pathologists and two whole-time technicians. In 1949 the total stiff was 25 . Ten years later there are eight whole-time pathologists, 21 whole-time technicians, 10 domestic and syringe service workers, and six clerical staff, a total of 45 . A variety of methods of keeping laboratory statistics have been used over the years and precise comparative figures are difficult to give. The 1944 report said. "The volume of work is about 23.000 specimens for the hospitals and 6,000 for borough councils and general practitioners," and memory suggests this probably means 4.000 were for G.P.s. For 19<9 the figures are: for hospitals and other institutions, 47,500 ; and for general practitioners, 10,700 (using part of the year as a basis of calculation). The G.P. work is therefore $18 \%$ of the total.

The propurtion of work for G.P.s has increased slightly while the grand total has more than doubled. Is this increase common to all practitioners and to both consultations (whether at the laboratory or in the home), and to specimens? In 1949 G.P.s were divided into three classes according to whether they used the laboratory fewer than $20,20-60$, and more than 60 times a year ; to make a similar comparison in 1959 it is necessary to divide into fewer than $40,40-120$, and more than 120 times. The two sets of figures are set out in the Table.

A most interesting point is at once apparent. The five highest users of the laboratory service scored 274 in 1949 and 277 in 1959. (They are not the same practi-
Average Frequency of Use of Laboratory*

\begin{tabular}{|c|c|c|c|c|c|c|c|c|}
\hline & \multicolumn{2}{|c|}{$\begin{array}{l}\text { No. of } \\
\text { G.P.s }\end{array}$} & \multicolumn{2}{|c|}{$\begin{array}{c}\text { No. of } \\
\text { Consultations }\end{array}$} & \multicolumn{2}{|c|}{$\begin{array}{c}\text { No. of } \\
\text { Specimens }\end{array}$} & \multicolumn{2}{|c|}{ Total } \\
\hline & 1949 & 1959 & 1949 & 1959 & 1949 & 1959 & 1949 & 1959 \\
\hline $\begin{array}{l}\text { (a) Lowest } \\
\text { (b) Middle } \\
\text { (c) Highest }\end{array}$ & $\begin{array}{l}41 \\
27 \\
30\end{array}$ & $\begin{array}{l}10 \\
43 \\
28\end{array}$ & $\begin{array}{r}3 \\
14 \\
63\end{array}$ & $\begin{array}{r}19 \\
50 \\
112\end{array}$ & $\begin{array}{r}5 \\
23 \\
68\end{array}$ & $\begin{array}{l}10 \\
26 \\
81\end{array}$ & $\begin{array}{r}8 \\
37 \\
131\end{array}$ & $\begin{array}{r}29 \\
76 \\
193\end{array}$ \\
\hline All & 98 & 81 & 24 & 69 & 29 & 43 & 53 & 112 \\
\hline $\begin{array}{l}\text { Five highest .. } \\
\text { Twelve lowest }\end{array}$ & $\begin{array}{r}5 \\
12\end{array}$ & $\begin{array}{r}5 \\
12\end{array}$ & $\begin{array}{r}155 \\
1\end{array}$ & $\begin{array}{r}159 \\
17\end{array}$ & $\begin{array}{l}119 \\
2 \cdot 5\end{array}$ & $\begin{array}{r}118 \\
9\end{array}$ & $\begin{array}{r}274 \\
3 \cdot 5\end{array}$ & $\begin{array}{r}277 \\
26\end{array}$ \\
\hline
\end{tabular}

* In 1949 the practitioners are here subdivided into those using the laboratory (a) fewer than 20 times a year, (b) 20 to 60 times, and (c) more than 60 times.

In 1959 the practitioners are here subdivided into those using the laboratory (a) fewer than 40 times a year, $(b)$ 40-120 times, and (c) more than 120 times.

tioners, though those still in practice of the original five are still high on the list.) Yet the overall average is just over twice the 1949 figure-112 as compared with 53 . It will be seen, therefore, that the change has been an overall increase in use by all practitioners. The 12 lowest cannot be derided, as was the imputation in the earlier paper, for they now make more than one-quarter of the average use of the laboratory, and the largest group is the "middle," who have greatly increased in number.

The pattern is a familiar one to all hospital administrators: provide a new service, and the general practitioners will learn to use it. Our experience would add that to base that service on "consultation" is to ensure that the service will not only be used but used wisely. The practitioners we are discussing are in almost daily communication with the laboratory, visiting personally or discussing cases and results on the telephone.

There are other services, and aspects of the consultative service, which bring the G.P. in contact with the laboratory. In the laboratory return for this year 29 institutions feature, some to only a very small extent. But six of these are hospitals at which general practitioners provide a considerable part of the service, and two, one inside and one outside the N.H.S., are run almost entirely by G.P.s These are serviced by the Kingston Group Laboratory and are visited daily or as required, so that the G.P. is in very close collaboration with the laboratory staff.

In the laboratory itself specialist services such as an allergy clinic, inoculations for yellow fever, estimations of basal metabolic rate, and so on, all call for close consultation. The central sterile-syringe service, which over the years has proved itself efficient and economical, brings many G.P.s on frequent visits to exchange their "Kingston syringe box" (Murray, 1954).

Anticoagulant therapy is a fairly recent development which has not only thrown much work on the laboratory but has cemented and "proved" the relationship between laboratory staff and G.P.s. A bedside service for prothrombin estimations is maintained ; and is continued on an out-patient basis as soon as patients are able to travel alone or by hospital car or ambulance service. So far as geography and other work permit, a patient is looked after continuously by the same pathologist. There is the closest co-operation on every clinical detail, but it is the pathologist who fixes the dose of anticoagulant as the result of his test. Tests are done as often as any case necessitates and are reduced in frequency as rapidly as safety permits. The accumulated experience of this problem is formidable. The prothrombin estimations have not 
been included in the figures given in the Table as they are more erratically used, by the accidental incidence of suitable cases in any practice, but the figures for prothrombin estimations follow the pattern of those in the Table in a somewhat exaggerated form, the highest users of the laboratory for other reasons apparently counting on the laboratory to keep their thromoosis cases at home. During the year 1959 just over 500 visits for the estimation of prothrombin times have been made in the homes of patients. There are already on the "prothrombin clinic" list some 300 patients, most of whom seem likely to be on permanent phenindione.

\section{Effect on Admissions to Hospital}

Laboratory costs were discussed in the earlier articles and it was suggested that in relation to a unit of population such as that served by the Kingston Group Laborat ary the cost was not high. In spite of the increase in work and the corresponding increase in staff wages and other costs that position still stands. But it is often asked to what extent a good open-access service saves hospital beds. One must, of course, also ask to what extent it saves lives; and here we can cite many examples of rapid action-for example, admission to hospital, by the laboratory staff, of cases urgently needing transfusion. But these are exceptional. ' Of the patients seen by the laboratory staff for general practitioners only a very small proportion are admitted to hospital. Many are of a type that might be admitted "for investigation" and occupy a hospital bed for some days or weeks but are diagnosed and treatment started without admission. Certainly the domiciliary service for anticoagulant therapy has paid for itself very handsomely in bed-units saved. The visiting pathologist and his G.P. colleagues occasionally decide that a case of thrombosis (all types are treated) should be sent in to hospital, but this is exceptional. An average of six to seven visits to the home of a patient is usually enough to control the dose of anticoagulant until the patient is fit to come to the weekly clinic.

\section{How Much More Pathology?}

This question has two aspects. Assuming that clinical pathology is static, how much more work can the G.P. put on to the laboratory? An exact answer would need a very detailed examination of the number of patients who reach the laboratory through the outpatient departments and not direct. Certainly a large number do, but many of these have been correctly routed by the G.P., who seeks a medical or surgical opinion rather than a laboratory diagnosis. But our figures suggest that even on this basis we are not yet doing all the clinical pathology we should. In 1951 we thought a fivefold increase should be budgeted for and we have had a $250 \%$ advance. If our middle and lowest users only reach the average we shall have nearly a further $25 \%$ increase ; and if we go on to the average of the 28 highest we still have a $75 \%$ increase to expect. But if all were to get up to our highest five then our 1951 calculation would still stand.

But clinical pathology is far from static. In 1951 we did not need to discuss the effect of anticoagulant therapy. To-day all sections of the laboratory work is advancing on a broad front. With our anticoagulant therapy goes a demand for time-consuming transaminase estimations; and liver-function tests occupy much laboratory time. A new test for cancer or rheumatism might push up the demand for laboratory service to an unsuspected figure; and the control of many new drugs involves the haematologist in many ways. Such increases will, of course, come from the needs of hospital consultants even more than general practitioners, and it looks as though administrators must be prepared to meet a rising demand for laboratory services in areas well served, and a very considerable rise in those parts of the country where development has been lagging.

\section{REFERENCES}

Murray, D. S. (1931). Pathology in a National Health Service. Socialist Medical Association.

- (1941). Lancet, 1, 187.

- (1944). Med. Press, 211, 166.

(1951). Brit. med. J., 2, Suppl. p. 15

(1954). Lancet, 1, 1274.

Nuffield Provincial Hospitals Trust (1941). A National Hospital Service. Oxford.

\section{APPROVED NAMES}

The last supplement to the consolidated list of "approved names" was published in the Journal of October 3, 1959 (p. 632). A new supplement, dated January, 1960, is printed below. Communications relating to "approved names" should be addressed to the secretary, British Pharmacopoeia Commission, General Medical Council, 44, Hallam Street, London, W.1.

\begin{tabular}{|c|c|c|}
\hline Approved Name & Other Names & Notes \\
\hline Bamethan & $\begin{array}{l}\text { 2-n-Butylamino-1-p-hydroxy- } \\
\text { phenylethanol } \\
\text { "Vasculit" is the sulphate }\end{array}$ & Vasodilator \\
\hline Bendrofluazide & $\begin{array}{l}\text { 3-Benzyl-3: 4-dihydro-7-sulpha- } \\
\text { moyl-6-trifluoromethyltenzo- } \\
1: 2: 4 \text {-thiadiazine } 1: 1 \text {-dioxide } \\
\text { " Aprinox" }\end{array}$ & Oral diuretic \\
\hline $\begin{array}{l}\text { Carbolonium } \\
\text { bromide }\end{array}$ & $\begin{array}{l}\text { Hexamethylenebis(carbamoyl- } \\
\text { choline bromide) } \\
\text { "Imbretil" " }\end{array}$ & Muscle relaxant \\
\hline Carisoprodol & 2-Carbamoyloxymethyl-2- $N$-iso- & $"$ \\
\hline $\begin{array}{l}\text { Cetylpyridinium } \\
\text { chloride }\end{array}$ & 1- Hexadecylpyridinium chloride & $\begin{array}{l}\text { Cationic surface } \\
\text { active agent }\end{array}$ \\
\hline Cyclandelate . & $\begin{array}{l}\text { 3: 3: 5-Trimethylcyclohexyl } \\
\text { mandelate } \\
\text { "Cyclospasmol" }\end{array}$ & Vasodilator \\
\hline Cyclophosphamide & $\begin{array}{l}\text { 2-[Di-(2-chloroethyl)amino]-1- } \\
\text { oxa-3-aza-2-phosphacyclo- } \\
\text { hexane 2-oxide } \\
\text { "Endoxan"; "Cytoxan" }\end{array}$ & Cytotoxic agent \\
\hline $\begin{array}{l}\text { Dextropropoxy- } \\
\text { phene* }\end{array}$ & $\begin{array}{l}\text { a-(+)-4-Dimethylamino-1: 2- } \\
\text { diphenyl-3-methyl-2-propionyl- } \\
\text { oxybutane } \\
\text { " Darvon" is the hydrochloride; } \\
\text { "Doloxene" is the hydro- } \\
\text { chloride }\end{array}$ & Narcotic analgesic \\
\hline Dimethoxanate & $\begin{array}{l}\text { 2-(2-Dimethylaminoethoxy)ethyl } \\
\text { phenothiazine-10-carboxylate }\end{array}$ & Antitussive \\
\hline Diphenadione & $\begin{array}{l}\text { 2-Diphenylacetylindane-1: 3- } \\
\text { dione } \\
\text { " Didandin"; " Dipaxin"; } \\
\text { "Oragulant", }\end{array}$ & Oral anticoagulant \\
\hline Diphenoxylate .. & $\begin{array}{l}\text { Ethyl 1-(3-cyano-3: 3-diphenyl- } \\
\text { propyl)4-phenyl-piperidine-4 } \\
\text { carboxylate }\end{array}$ & $\begin{array}{l}\text { Antidiarrhoeal agent } \\
\text { (narcotic typo) }\end{array}$ \\
\hline Disulphamide .. & $\begin{array}{l}\text { 5-Chloro-2: 4-disulphamoyl- } \\
\text { "tnluene } \\
\text { "Disamide" }\end{array}$ & Oral diuretic \\
\hline Heptabarbitone & $\begin{array}{l}\text { 5-Ethyl-5-cyclohept-1'-enylbar- } \\
\text { bituric acid } \\
\text { "Medomin" }\end{array}$ & Hypnotic \\
\hline Nialamide & $\begin{array}{l}N \text {-(2-Benzylcarbamoylethyl)- } N \text { '- } \\
\text { isonicotinoyl-hydrazine } \\
\text { "Niamid" }\end{array}$ & Antidepressant \\
\hline Phenazocine & $\begin{array}{l}\text { 2'-Hydroxy-5: 9-dimethyl-2- } \\
\text { phenethyl-6: 7-benzomorphan }\end{array}$ & Narcotic analgesic \\
\hline coum & $\begin{array}{l}\text { 4-Hydroxy-3-(1-phenylpropyl)- } \\
\text { "coumarin } \\
\text { "Marcoumar" }\end{array}$ & Oral anticoagulant \\
\hline $\begin{array}{l}\text { Salazosulphadimi- } \\
\text { dine }\end{array}$ & $\begin{array}{l}\text { 4'-(4: 6-Dimethylpyrimid-2- } \\
\text { ylsulphamoyl)-4-hydroxyazo- } \\
\text { benzene-3-carboxylic acid } \\
\text { " Azudimidine" }\end{array}$ & Sulphonamido \\
\hline Sulphaphenazole & $\begin{array}{l}\text { 5-p-Aminohenzenesulphon- } \\
\text { amido-1-phenylpyrazole } \\
\text { "Orisulf" }\end{array}$ & $"$ \\
\hline Tetrahydrozoline & $\begin{array}{l}\text { 2-(1:2:3: 4-Tetrahydro-1- } \\
\text { naphthyl)imidazoline } \\
\text { " Tyzanol " is the hydrochloride }\end{array}$ & Vasoconstrictor \\
\hline Trir & $\begin{array}{l}\text { Tri-(2-chloroethyl)amine } \\
\text { "Trillekamin " }\end{array}$ & Cytotoxic agent \\
\hline
\end{tabular}

Replaces the approved name propoxyphen
1 : 2-diphenyl-3-methyl-2-propionyloxybutane. 